\title{
PENGARUH RETURN ON ASSET, DEBT TO EQUITY RATIO, NET PROFIT MARGIN TERHADAP INCOME SMOOTHING DENGAN VARIABEL MODERASI PROPORSI WANITA DI DALAM DEWAN DIREKSI (STUDI KASUS PADA PERUSAHAAN MANUFAKTUR YANG TERDAFTAR DI BURSA EFEK INDONESIA PADA TAHUN 2013- 2015)
}

\author{
Yolita Kurniawati \\ Paulus Sulluk Kananlua \\ Sugeng Susetyo \\ Fakultas Ekonomi dan Bisnis Universitas Bengkulu
}

\begin{abstract}
This study aims to investigate the effect of: (1) Return on Asset (ROA), Debt to Equity Ratio (DER), Net Profit Margin (NPM), and the proportion of women in board of directors on income smoothing. (2) Further, this study also investigates the moderating effect of proportion of women in board of directors on effect of ROA, DER, and NPM to income smoothing. Data were collected from manufacture companies listed on the Indonesia Stock Exchange (IDX) in the year of 2013-2015. Multiple regression analysis and moderated regression analysis were used to test the hypotesis in this study. The results of multiple regression analysis show that Return on Asset (ROA) and Debt to Equity Ratio (DER) influence the income smoothing. Meanwhile, Net Profit Margin (NPM) does not influence the income smoothing. The result of moderated regression analysis shows that the proportion of women does not moderate the effect of Return on Asset (ROA), Debt to Equity Ratio (DER), and Net Profit Margin (NPM) on income smoothing. Those could happen because very women are sit in the Board of Directors of the firms in Indonesia.
\end{abstract}

Keywords: Income Smoothing, Return on Asset (ROA), Debt to Equity Ratio (DER), Net profit Margin (NPM).

\section{PENDAHULUAN}

\section{Latar Belakang}

Manajemen laba pada prinsipnya merupakan strategi pengelolaan dan pengambilan keputusan yang dapat digunakan oleh perusahaan untuk mengelola laba yang dimiliki. Manajemen laba menjadi salah satu strategi yang perlu dilakukan oleh suatu perusahaan. Manajemen laba memiliki peran penting dalam mengelola laba di dalam laporan keuangan perusahaan. Hal ini karena manajemen laba berkaitan 
dengan keputusan yang akan diambil oleh perusahaan yang akan memengaruhi kinerja dari perusahaan dan masa depan perusahaan.

Manajemen bertanggung jawab atas setiap kegiatan yang dilakukan terhadap sumber daya pemilik perusahaan atau pemodal melalui laporan keuangan dan salah satu ukuran yang dapat digunakan untuk mengukur kinerja manajemen yaitu laba. Informasi laba merupakan komponen laporan keuangan perusahaan yang bertujuan untuk menilai kinerja manajemen, membantu mengestimasi kemampuan laba dalam jangka panjang, dan menafsirkan risiko investasi atau meminjamkan dana. Selain itu, informasi laba membantu pemilik atau pihak lain melakukan penafsiran atas kemampuan laba perusahaan di masa yang akan datang (Putra dan Rahmanti, 2013).

Pentingnya informasi laba cenderung dapat mengatasi berbagai konflik kepentingan antara pihak manajemen dengan pihak di luar bisnis, khususnya investor dan kreditor, manajemen melakukan manajemen laba. Sebagian besar pihak manajemen menyadari hal tersebut sehingga pihak manajemen cenderung melakukan perilaku pelaporan laba yang tidak semestinya. Tindakan manajemen laba dapat dilakukan dalam berbagai bentuk, antara lain taking bath, income maximization, income minimization, dan income smoothing. Penelitian ini terfokus pada tindakan manajemen laba berupa perataan laba (income smoothing) yang merupakan suatu tindakan manajemen untuk mengurangi fluktuasi laba atau membuat laba seolaholah stabil dalam kurun waktu lama. Perataan laba dilakukan dengan cara penggunaan teknik-teknik tertentu untuk memperkecil atau memperbesar jumlah laba suatu periode sama atau mendekati jumlah laba periode sebelumnya.

\section{METODE PENELITIAN}

\section{Desain Penelitian}

Jenis penelitian yang digunakan pada penelitian ini adalah jenis penelitian explanatory (explanatory research). Penelitian eksplanatory (explanatory research) merupakan penelitian penjelasan yang menyoroti hubungan kausal antara variabelvariabel penelitian dan menguji hipotesis yang telah dirumuskan sebelumnya (Singarimbun dan Effendy, 1995:[4]). Penelitian ini bersifat kuantitatif, menggunakan variabel dependen, variabel independen, dan variabel moderasi.

\section{Metode Pengumpulan Data}

Data dalam penelitian ini merupakan data sekunder. Metode pengumpulan data menggunakan cara dokumentasi dari laporan keuangan yang ada di www.idx.co.id atau dari situs lainnya seperti www.sahamok.com. Pengambilan data dilakukan dengan mengambil data laporan keuangan dari perusahaan manufaktur yang terdaftar di Bursa Efek Indonesia (BEI) tahun 2013 - 2015. 


\section{Metode Pengambilan Sampel \\ Populasi}

Populasi di dalam penelitian ini adalah 145 perusahaan manufaktur yang terdaftar di BEI periode 2013-2015.

\section{Sampel}

Penelitian ini menggunakan metode nonprobability sampling dengan teknik purposive sampling, yaitu pengambilan sampel dilakukan hanya atas dasar pertimbangan penelitinya saja yang menganggap unsur-unsur yang dikehendaki telah ada dalam anggota sampel yang diambil.

\section{Teknik Analisis Data}

Menggunakan teknik analisis regresi linear berganda dan moderated regression analysis (MRA) untuk melihat pengaruh antar variabel. Penelitian ini menggunakan Logaritma Natural (LN) untuk mengurangi bias data yang terlalu besar.

\section{HASIL DAN PEMBAHASAN}

\section{Hasil Regresi Berganda}

Penelitian ini menganalisis pengaruh variabel Return on Asset (ROA), Debt to Equity Ratio (DER), Net Profit Margin (NPM) serta proporsi wanita dalam dewan direksi sebagai variabel moderasi terhadap income smoothing perusahaan manufaktur yang terdaftar di Bursa Efek Indonesia periode 2013-2015, dimana hasil persamaan regresi dapat dilihat pada Tabel 1 berikut:

Tabel 1

Regresi Linear Berganda

\begin{tabular}{|c|c|c|c|c|c|c|}
\hline & \multirow[b]{2}{*}{ Model } & \multicolumn{2}{|c|}{$\begin{array}{l}\text { Unstandardized } \\
\text { Coefficients }\end{array}$} & \multirow{2}{*}{$\begin{array}{c}\text { Standardized } \\
\text { Coefficients }\end{array}$} & \multirow[b]{2}{*}{$\mathrm{t}$} & \multirow[b]{2}{*}{ Sig. } \\
\hline & & E & Std. Error & & & \\
\hline \multirow[t]{5}{*}{1} & (Constant) & -.928 & .383 & & -2.419 & .024 \\
\hline & LNROA & -.722 & .283 & -.951 & -2.556 & .018 \\
\hline & LNDER & -.212 & .098 & -.368 & -2.150 & .043 \\
\hline & LNNPM & 395 & .294 & .551 & 1.342 & 193 \\
\hline & $\begin{array}{l}\text { LNProporsiWanit } \\
\text { a }\end{array}$ & 259 & .116 & .350 & 2.240 & .035 \\
\hline
\end{tabular}

a. Dependent Variable: LNIncomeSmoothing

Sumber: Data yang diolah (2017) 
Kemudian dilakukan Antilog pada Beta di dalam variabel penelitian ini yang terdiri dari LNROA, LNDER dan LNNPM dengan hasil sebagai berikut:

Tabel

Antilog Beta

\begin{tabular}{|l|l|l|}
\hline Model & B & Antilog B \\
\hline Constan & -0.928 & -8.472 \\
\hline LNROA & -0.722 & -5.272 \\
\hline LNDER & -0.212 & -1.629 \\
\hline LNNPM & 0.395 & 2.483 \\
\hline
\end{tabular}

Allen Wyat,"Deriving Antilogs"

(https://excel.tips.net/T002171 Deriving Antilogs.html diakses 27 Juli 2017)

Persamaan regresi linear berganda dalam penelitian ini menggunakan koefisien beta tidak standar (unstandardized coefficients). Hal ini disebabkan karena masingmasing variabel memiliki satuan dan fungsi untuk menjelaskan besarnya tingkat koefisien regresi masing-masing variabel bebas dalam menerangkan variabel terikat, penelitian ini juga menggunakan Logaritma Natural (LN) untuk mengurangi bias data yang terlalu besar dan dilakukan antilog dengan hasil sebagai berikut:

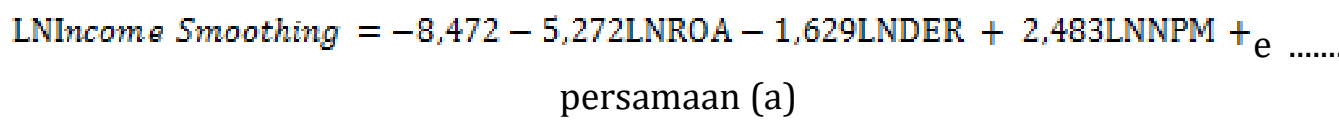

Dari persamaan tersebut dapat dijelaskan sebagai berikut :

a. Konstanta sebesar -8,472 menunjukkan jika Return on Asset (ROA), Debt to Equity Ratio (DER), Net Profit Margin (NPM) nilainya adalah 0, maka Income Smoothing nilainya negatif sebesar -8,472 sebelum dimoderasi oleh proporsi wanita di dalam dewan direksi. Yang dapat berarti bahwa apabila Return on Asset (ROA), Debt to Equity Ratio (DER), dan Net Profit Margin (NPM) nilainya tinggi maka maka mengurangi motivasi motivasi manajemen untuk melakukan Income Smoothing.

b. Koefisien regresi Return on Asset (ROA) sebesar -5,272 menunjukkan Return on Asset (ROA) mempunyai pengaruh yang negatif terhadap Income Smoothing, sehingga dapat disimpulkan bahwa laba perusahaan yang rendah memotivasi manajemen perusahaan untuk melakukan tindakan income smoothing. Hal ini karena investor lebih menyukai laba yang rata sehingga perusahaan terlihat sehat dan baik. 
c. Koefisien regresi Debt to Equity Ratio (DER) sebesar -1,629 dimana menunujukkan jika Debt to Equity Ratio (DER) mempunyai pengaruh negatif terhadap income smoothing, sehingga dapat disimpulkan bahwa hutang tinggi yang dimiliki perusahaan memotivasi manajemen untuk melakukan income smoothing. Hal ini agar perusahaan tampak baik dimata investor dan kinerjanya juga baik.

d. Koefisien Net Profit Margin (NPM) sebesar 2,483 dimana menunjukkan jika Net Profit Margin (NPM) mempunyai pengaruh positif terhadap income smoothing, sehingga dapat simpulkan bahwa pendapatan yang tinggi yang dihasilkan oleh perusahaan memicu perusahaan untuk melakukan tindakan income smoothing

\section{Moderated Regression Analysis (MRA)}

Penelitian ini juga menggunakan Moderated Regression Analysis (MRA) untuk mengetahui pengaruh dari variabel moderasi yang pada penelitian ini merupakan wanita dalam dewan direksi perusahaan. Dimana hasil regresi dapat dilihat pada tabel berikut:

Tabel

Moderated Regression Analysis

Coefficients $^{\mathbf{a}}$

\begin{tabular}{|c|c|c|c|c|c|c|}
\hline \multirow{2}{*}{\multicolumn{2}{|c|}{ Model }} & \multicolumn{2}{|c|}{$\begin{array}{l}\text { Unstandardized } \\
\text { Coefficients }\end{array}$} & \multirow{2}{*}{ 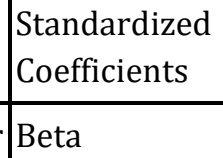 } & \multirow[b]{2}{*}{$\mathrm{t}$} & \multirow[b]{2}{*}{ Sig. } \\
\hline & & B & Std. Error & & & \\
\hline \multirow[t]{8}{*}{2} & (Constant) & -1.078 & .444 & & -2.426 & .025 \\
\hline & LNROA & -1.027 & .418 & -1.352 & -2.454 & .024 \\
\hline & LNDER & -.185 & .236 & -.321 & -.781 & .444 \\
\hline & LNNPM & .643 & .403 & .896 & 1.596 & .127 \\
\hline & LNProporsiWanita & .336 & .431 & .453 & .779 & .445 \\
\hline & $\begin{array}{l}\text { LNROA.ProporsiWanit } \\
\text { a }\end{array}$ & .699 & .646 & 2.693 & 1.082 & .293 \\
\hline & $\begin{array}{l}\text { LNDER.ProporsiWanit } \\
\mathrm{a}\end{array}$ & -.065 & .242 & -.129 & -.268 & .791 \\
\hline & $\begin{array}{l}\text { LNNPM.ProporsiWanit } \\
\text { a }\end{array}$ & -.667 & .616 & -2.746 & -1.083 & .292 \\
\hline
\end{tabular}

a. Dependent Variable: LNIncomeSmoothing

Sumber: Data yang diolah (2017) 
Kemudian dilakukan Antilog pada Beta di dalam variabel penelitian ini yaitu pada variabel pemoderasi ROA.Proporsi Wanita sebagai moderasi ROA terhadap income smoothing, DER.Proporsi Wanita sebagai moderasi DER terhadap income smoothing, dan NPM.Proporsi Wanita sebagai variabel moderasi NPM terhadap income smoothing dengan hasil sebagai berikut:

Tabel

Antilog Beta

\begin{tabular}{|l|l|l|}
\hline Model & B & AntilogB \\
\hline Constan & -1.078 & -11.967 \\
\hline LNROA.ProporsiWanita & 0.699 & 5.000 \\
\hline LNDER.ProporsiWanita & -0.065 & -1.161 \\
\hline LNNPM.ProporsiWanita & -0.667 & -4.465 \\
\hline
\end{tabular}

Allen Wyat,"Deriving Antilogs"

(https://excel.tips.net/T002171 Deriving_Antilogs.html diakses 27 Juli 2017)

Moderated Regression Analysis (MRA) atau uji interaksi merupakan aplikasi khusus regresi berganda linear dimana dalam persamaan regresinya mengandung unsur interaksi (perkalian dua atau lebih variabel independen) maka rumus regresi ini dapat dinyatakan sebagai berikut:

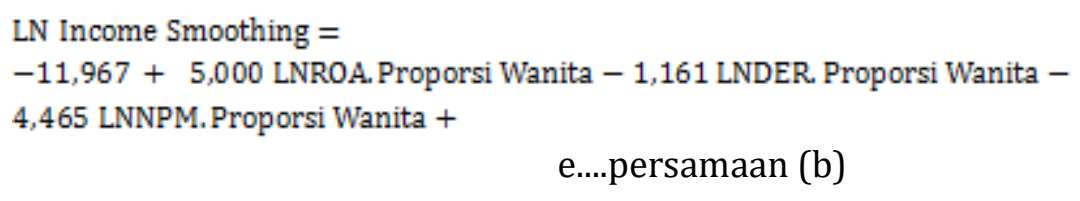$$
\text { e....persamaan (b) }
$$

e. Konstanta sebesar -11,967 menunjukkan bahwa jika pengaruh pada Return on Asset (ROA), Debt to Equity Ratio (DER) dan Net Profit Margin (NPM) dengan di moderasi proporsi wanita di dalam dewan direksi adalah 0 , maka income smoothing nilainya negative sebesar $-11,967$ setelah dimoderasi oleh proporsi wanita di dalam dewan direksi.

f. Koefisien regresi Return on Asset (ROA) terhadap income smoothing dengan dimoderasi proporsi wanita di dalam dewan direksi sebesar 5,000 yang menunjukkan bahwa proporsi wanita di dalam dewan direksi perusahaan sebagai variabel moderasi memiliki pengaruh positif antara Return on Asset (ROA) terhadap income smoothing, yang menunjukkan bahwa semakin banyaknya proporsi dewan direksi wanita di dalam sebuah perusahaan akan 
dapat meningkatkan Return on Asset yang akan memperkuat tindakan pihak manajemen untuk mengurangi income smoothing karena sikap direksi wanita yang cenderung berlaku selaras dengan kebijakan dan peraturan perusahaan.

g. Koefisien regresi Debt to Equity Ratio (DER) terhadap income smoothing dengan dimoderasi proporsi wanita di dalam dewan direksi sebesar -1,161 yang menunjukkan bahwa proporsi wanita di dalam dewan direksi perusahaan sebagai variabel moderasi memiliki pengaruh negatif antara Debt to Equity Ratio (DER) terhadap income smoothing, yang menunjukkan bahwa semakin banyak proporsi dewan direksi wanita di dalam sebuah perusahaan akan dapat menurunkan Debt to Equity Ratio (DER) yang akan memperkuat tindakan pihak manajemen untuk mengurangi income smoothing karena sikap direksi wanita yang cenderung patuh dengan kebijakan dan peraturan perusahaan.

h. Koefisien regresi Net Profit Margin (NPM) terhadap income smoothing dengan dimoderasi proporsi wanita di dalam dewan direksi sebesar -4,465 yang menunjukkan bahwa proporsi wanita di dalam dewan direksi perusahaan sebagai variabel moderasi memiliki pengaruh negative antara Net Profit Margin (NPM) terhadap income smoothing, yang menunjukkan bahwa apabila Net Profit Margin (NPM) mengalami peningkatan dengan adanya proporsi dewan direksi wanita yang lebih banyak, maka akan memperlemah tindakan manajemen untuk melakukan income smoothing karena dewan direksi wanita cenderung lebih mempertimbangkan risktaking untuk menghindari resiko. Dengan demikian, pihak dewan direksi selalu menjaga laba perusahaan untuk bergerak stabil mengikuti kestabilan aktivitas penjualan.

\section{KESIMPULAN DAN SARAN}

\section{Kesimpulan}

Berdasarkan hasil penelitian dan pembahasan, maka dapat diambil kesimpulan sebagai berikut:

a. Hasil pengujian hipotesis secara parsial untuk variabel Return on Asset (ROA) terhadap income smoothing diperoleh bahwa Return on Asset (ROA) berpengaruh secara negatif signifikan terhadap income smoothing pada perusahaan manufaktur yang terdaftar di Bursa Efek Indonesia periode 
2013-2015. Oleh karena itu diharapkan untuk manajemen lebih informatif dalam menyampaikan informasi dalam pengelolaan labanya kepada pengguna informasi (investor, dll) dan diharapkan juga kepada investor untuk lebih teliti menerima informasi yang disampaikan perusahaan.

b. Hasil pengujian hipotesis secara parsial untuk variabel Debt to Equity Ratio (DER) terhadap income smoothing diperoleh bahwa Debt to Equity Ratio (DER) berpengaruh secara negatif signifikan terhadap income smoothing pada perusahaan manufaktur yang terdaftar di Bursa Efek Indonesia periode 2013-2015. Perusahaan ini sebaiknya memang mengolah informasi sebaik mungkin yang berhubungan dengan kegiatan perusahaan, baik dari segi laba maupun segi hutang karena pengguna informasi menggunakan seluruh informasi untuk kemudian mengambil keputusan investasinya.

c. Hasil pengujian hipotesis secara parsial untuk variabel Net Profit Margin (NPM) terhadap income smoothing diperoleh bahwa Net Profit Margin (NPM) tidak berpengaruh secara signifikan terhadap income smoothing pada perusahaan manufaktur yang terdaftar di Bursa Efek Indonesia periode 2013-2015. Yang dapat disebabkan karena perusahaan belum mampu mensatbilkan penjualannya sehingga tidak melakukan tindakan yang berbahaya bagi perusahaan. Oleh karena itu diharapkan untuk manajemen lebih informatif dalam menyampaikan informasi keuangan dalam pengelolaan labanya kepada pengguna informasi terutama investor.

d. Hasil pengujian hipotesis secara parsial untuk variabel moderasi yaitu proporsi wanita di dalam dewan direksi terhadap income smoothing diperoleh bahwa proporsi wanita di dalam dewan direksi tidak berpengaruh secara signifikan (tidak memoderasi pengaruh ROA, DER dan NPM) terhadap income smoothing pada perusahaan manufaktur yang terdaftar di Bursa Efek Indonesia periode 2013-2015. Yang disebabkan oleh masih sedikitnya wanita yang duduk dalam jajaran dewan terutama di Indonesia.

\section{Saran}

Berdasarkan hasil penelitian ini maka saran yang dapat diberikan pada penelitian ini adalah sebagai berikut:

\section{Bagi Perusahaan}

Apabila ingin melakukan income smoothing perlu untuk memperhatikan berbagai faktor seperti Return on Asset (ROA), Debt to Equity Ratio (DER), Net Profit Margin (NPM) karena tingkat pengembalian laba bagi perusahaan sangat mempengaruhi keputusan untuk melakukan income smoothing, sedangkan DER yang tinggi akan 
memberikan tingkat pengembalian laba yang lebih. Laba yang tinggi akan membuat manajemen cenderung untuk melakukan tindakan income smoothing. Hal ini dapat disebabkan perusahaan manufaktur lebih mempertimbangkan reputasi serta hal lain yang berhubungan dengan nilai perusahaan baik dimata investor ataupun masyarakat. Selain itu, perusahaan juga perlu untuk memperbanyak dewan direksi wanita karena dalam penelitian ini diketahui bahwa dewan direksi wanita di dalam perusahaan manufaktur masih sedikit hingga informasi yang disajikan cenderung rentan untuk tidak sesuai dengan kenyataan pada perusahaan.

2. Bagi Investor

Diperlukan kecermatan dan ketelitian dalam melihat informasi yang disajikan perusahaan. Karena bisa saja perusahaan melakukan manajemen laba salah satunya income smoothing seperti pada penelitian ini dengan alasan tertentu. Oleh karena itu investor harus lebih berhati-hati dalam mengelola informasi agar tidak terjadi kesalahan dalam pengambilan keputusan terutama dalam berinvestasi.

3. Bagi Penelitian Selanjutnya

Untuk penelitian selanjutnya perlu menambahkan variabel lainnya yang berpengaruh terhadap income smoothing, dapat menggunakan perusahaan lain sebagai sampel untuk melihat apakah ada tindakan income smoothing atau tidak di dalam perusahaan, di dalam laporan keuangan perusahaan. Kemudian variabel moderasi bisa menggunakan variabel lain untuk melihat apakah ada hubungannya dengan variabel lain yang bersangkutan.

\section{DAFTAR PUSTAKA}

Aini N. (2013). Pengaruh CAR, NIM, LDR, NPL, BOPO, dan Kualitas Aktiva Produktife terhadap Perubahan Laba. Dinamika Akuntansi, Keuangan dan Perbankan, Mei 2013, Hal: 14 - 25 Vol. 2, No. 1

Aji, D. Y., dan A. F. Mita. (2010). "Pengaruh Profitabilitas, Risiko Keuangan, Nilai Perusahaan dan Struktur Kepemilikan Terhadap Praktek Perataan Laba: Studi Empiris Perusahaan Manufaktur Yang Terdaftar Di BEI", Makalah Simposium Nasional Akuntansi, XIII, Purwokerto.

Alwiyah dan Solihin, Charis. (2015). Pengaruh income smoothing terhadap earnings response pada perusahaan manufaktur yang terdaftar di BEI. Jurnal performance, Bisnis dan Akuntansi Volume V,No.2,September.

Angkoso, Willy, Ciptadi. 2006. Pengaruh Debt to Equity Ratio dan Return on Equity terhadap Pertumbuhan Laba.Skripsi Jurusan Ekonomi UNNES.

Ashari, Nasuniyah., Hian C. Koh, Soh L. Tan, and Wei H. Wong. 1994. Factors Affecting Income Smoothing Among Listed Companies in Singapore. Accounting and Business Research. Vol 24, No. 96: 291-301. 
Assih, Prihat dan M. Goedono. (2000). Hubungan Tindakan Perataan Laba dengan Reaksi Pasar atas Pengumuman Informasi Laba Perusahaan yang Terdaftar di Bursa Efek Jakarta. Jurnal Riset Akuntansi Indonesia, Januari Vol. 3: 3553.

Atik, Asuman. 2008. "Detecting income-smoothing behaviors of Turkish listed companies through empirical test using discretionary accounting changes".Critical Perspectives on Accounting, Vol.20, p. 591-613.

Azhar, Susanto. (2008). Sistem Informasi Akuntansi, Struktur Pengendalian Resiko dan Pengembangan, Edisi Perdana, Bandung : Lingga Jaya.

Bastian, Indra dan Suhardjono. 2006. Akuntansi Perbankan. Edisi 1. Jakarta : Salemba Empat.

Budhijono, Fongnawati. (2006). Evaluasi Perataan Laba Pada Industri Manufaktur dan Lembaga Keuangan yang Terdaftar di BEJ. Akuntabilitas. Vol 6 (1) Hal: 70-79

Budiasih I G A N. (2009). Faktor-Faktor yang Mempengaruhi Praktik Perataan Laba.

Belkoui dan Ahmed Riahi. (2000). Teori Akuntansi (Terjemahan) Buku 1 dan 2. Edisi 4. Penerbit Salemba Empat, Jakarta.

Dedy, I. (2014). Pengaruh CAR, NPL, NPM, BOPO dan LDR terhadap ROA.

Faizah, 2009, "Faktor-Faktor yang Berpengaruh terhadap Tindakan Perataan

Laba (Income Smoothing) pada Perusahaan yang termasuk dalam Jakarta

Islamic Index".

Gayatri A,D dan Made. Tanpa Tahun. Faktor-Faktor yang mempengaruhi perataan laba perusahaan manufaktur yang terdaftar di Bursa Efek Indonesia.

Gardiner, M., dan Tiggemann, M. (1999). Gender Differences in Leadership Style, Job Stress, and Mental Health in Male - and Female - Dominate Industries. Journal of Occupational and Organizational Psychology. 72:301-315

Ghozali, Imam. (2013). Aplikasi Analisis Multivarite dengan Program IBM SPSS 21. Edisi 7. Universitas Diponegoro, Semarang

Gunawan Ketut I, Darmawan Surya A N, dan Purnamawati A G. (2015). Pengaruh Ukuran Perusahaan, Profitabilitas, Dan Leverage terhadap Manajemen Laba pada Perusahaan Manufaktur yang terdaftar di Bursa Efek Indonesia (BEI) . Jurusan Akuntansi Program S1 (Volume 03, No.01 Tahun 2015)

Herawaty dan Suwinto. (2005). Analisis Pengaruh Karakteristik Perusahaan terhadap Tindakan Perataan Laba yang dilakukan oleh Perusahaan yang Terdaftar di Bursa Efek Jakarta. Simposium Nasional Akuntansi VIII. 15-16 September. Solo.

Iskandar Fajar A dan Suardana Ketut I. (2016). Pengaruh Ukuran Perusahaan, Return On Asset, dan Winner/Loser Stock terhadap Praktik Perataan Laba. E-Jurnal Akuntansi Universitas Udayana.14.2 Februari (2016). 805-834

Jamilah,S;Fanami,Z; dan Chandrarin,G. (2007). Pengaruh Gender, Tekanan Ketaatan, Kompleksitas Tugas terhadap Audit Judgement.

Junita,S dan Khairani, S. Tanpa Tahun. Analisis Kinerja Keuangan dengan Menggunakan Analisa Rasio Keuangan Pada Perusahaan Telekomunikasi yang Terdaftar di Bursa Efek Indonesia. Jurnal Manajemen.

Juniarta Agus W. I dan Sujana Ketut I. (2015). Pengaruh Financial Leverage pada Income Smoothing dengan Good Corporate Governance Sebagai Variabel Pemoderasi. E-Jurnal Akuntansi Universitas Udayana 11.3 :921-939 
Josep;H;W, AR Dzulkirom;M, dan Azizah;F;D. (2016). Pengaruh ukuran perusahaan, Return On Asset dan Net Profit Margin terhadap perataan laba (income smoothing). Jurnal Administrasi Bisnis (JAB). Vol. 33 No. 2 April 2016.

Andi Kartika. 2012. Pengaruh Kondisi Keuangan dan Non Keuangan terhadap Penerimaan Opini Going Concern pada Perusahaan Manufaktur di BEI, Dinamika Akuntansi Keuangan dan Perbankan, Vol. 1 No.1, Mei 2012.

Kristanti, P. (2010). Tingkat Variasi Gender Posisi Manajemen Puncak dan Kualitas Laba Perusahaan. Jurnal Riset Akuntansi dan Keuangan. Vol. 6 No. 2, Agustus 2010 Hal. 87-98

Kusumaningrostati, A dan Mutasowifin, A. (2014). Analisis Pengaruh Faktor-Faktor Income Smoothing dengan Gender sebagai Variable moderator pada emiten perbankan. Jurnal Manajemen dan Organisasi. Vol V No 2.

Kustini, D. dan E. Ekawati. (2006). Analisis Perataan Laba dan Fktor - Faktor yang mempengaruhi : Studi Empiris pada Perusahaan di Indonesia. Jurnal Riset.

Peranasari, I.A.A.I dan Dharmadiaksa Bagus I. (2014). Perilaku Income Smoothing, dan Faktor-Faktor yang Mempengaruhinya. E-Jurnal Akuntansi Universitas Udayana 8.1:140-153

Pratiwi O.S dan Mahastanti A.L. (2013). Fenomena Perataan Laba di Indonesia: Garbling vs Signalling. Among Makarti Vol.6 No.11, Juli 2013

Pradana,W.A dan Sunaryo. (2012). Analisis Pengaruh Company Size, Return On Assets, Financial Leverage, dan Operating Leverage terhadap Income Smoothing Practices pada Perusahaan Manufaktur yang terdaftar di Bursa Efek Indonesia. BINUS BUSINESS REVIEW Vol. 3 No. 1 Mei 2012: 131-140

Prabayanti A.P.L.N dan Yasa Wirawan G. Tanpa Tahun. Perataan Laba (Income Smoothing) dan Faktor yang Mempengaruhinya.

Pradnyanika, Desak Made.2007.Pengaruh Net Profit Margin dan Leverage Operasi Terhadap Perataan Laba pada Perusahaan Farmasi di BEJ Periode Tahun 2003-2005. Skripsi Sarjana Jurusan Akuntansi, Fakultas Ekonomi, Universitas Udayana Denpasar.

Putra;D; R.A dan Rahmanti,W dan. Return dan Resiko Saham Pada Perusahaan Perata Laba dan Bukan Perata Laba. Jurnal Dinamika Akuntansi. Vol. 5, No. 1, Maret 2013.

Rahnita, D. (2012). Analisis Faktor-Faktor yang Mempengaruhi Perataan Laba Pada Perusahaan Manufaktur yang tercatat di Bursa Efek Indonesia Periode Tahun 2007-2010. Skripsi. Semarang: Universitas Diponegoro.

Rianti,Ina. Tanpa Tahun. Pengaruh Net Profit Margin (NPM), Return On Asset (ROA) dan Return On Equity (ROE) terhadap Harga Saham pada Perusahaan yang Tercantum Dalam Indeks LQ45. Jurusan Akuntansi, Fakultas Ekonomi, Universitas Gunadarma

Salim S. (2014). Analisis Faktor-Faktor yang mempengaruhi Tindakan Perataan Laba pada Perusahaan Perbankan Di Bursa Efek Indonesia. Jurnal Wira Ekonomi Mikroskil. Volume 4, Nomor 02, Oktober 2014

Salno dan Baridwan (2000:19)," teori earning management: definisi, pola dan faktor yang mendorong manajemen melakukan earning management".

Sari VMN dan Budiasih. (2014). Pengaruh Debt Equity Ratio, Firm Size, Inventory Turnover dan Assets Turnover Pada Profitabilitas. E-Jurnal Akuntansi Universitas Udayana 6.2 (2014):261-273 
Scott, William R. 2000. Financial Accounting Theory. USA : Prentice-Hall.

Septoaji, Arwinto. (2002). Analisis Faktor-Faktor yang mempengaruhi Perataan Laba (Income Smoothing) di Bursa Efek Jakarta. Tesis. Universitas Diponegoro Semarang.

Siagian, Pariang. (2015). Analisis Pengaruh Kinerja Keuangan terhadap Perataan Laba pada Perusahaan Perbankan Terbuka di Indonesia. Binus Bussiness Review Vol.6 No.1 Mei 2015:57-66

Singarimbun, Masri dan Effendi. 1995. Metode Penelitian Survai. Jakarta : Pustaka LP3ES.

Sugiyono. (2009). Metode Penelitian Bisnis. Cetakan Kedelapan. CV Alfabeta, Bandung

Suryandari A N N. ( 2012). Analisis Faktor-Faktor yang mempengaruhi Income Smoothing. Media Komunikasi FIS Vol. 11 .No 1 April 2012:1-15

Suryani dan Damayanti. (2015). Pengaruh Ukuran Perusahaan, Debt to Equity Ratio, Profitabilitas dan Kepemilikan Institusional pada Perataan Laba. -Jurnal Akuntansi Universitas Udayana 13.1 (2015): 208-223

Susanto,K;Y dan Pradipta,A. (2008). Faktor- Faktor yang mempengaruhi perataan laba. Media Bisnis, September.

Sumtaky, Olivia M.(2007). "Faktor - Faktor Yang Mempengaruhi Praktik Perataan Laba pada perusahaan Manufaktur yang terdaftar di BEJ (2003-2005)." Skripsi. Universitas Brawijaya Malang.

Utomo, S.Budiman., dan Baldric Siregar., 2008, Pengaruh Ukuran Perusahaan, Profitabilitas, dan Kontrol Kepemilikan Terhadap Perataan Laba PadaPerusahaan Manufaktur Yang Terdaftar Di Bursa Efek Indonesia (BEI),Jurnal Akuntansi dan Manajemen, Vol. 19, No. 2, Agustus,Hal : 113125.

Wahyuni Eka A, Sambarhakresna Y, dan Carolina A. (2013). Analisis Faktor-Faktor yang mempengaruhi Income Smoothing. JAFFA Vol. 01 No. 1 April 2013 Hal. $39-52$

Yurianto, Priyo Sajarwo dan Gudono. 2002. Faktor-Faktor Yang Mempengaruhi Perataan Laba Pada Perusahaan-Perusahaan Yang Terdaftar di Pasar Modal Utama ASEAN. Kompak. No.5 Hal: 119-138

www.idx.co.id

www.sahamok.com

www.suaramerdeka.com/harian/0302/24/eko1.htm

http://www.nakertrans.go.id 